\title{
Spaces of Rupture: Wondering, Wandering, Remixing
}

\author{
Cathy Benedict \\ University of Western Ontario
}

This response is based on my presentation at Teachers College, Columbia University celebrating the launch of Allsup's (2016) book, Remixing the Classroom: Toward an Open Philosophy of Music Education. I enter the text with openness, and with a willingness to ponder and consider. As such I offer the following considerations for further "thinking through." These are considerations, given the context of the book, I feel are necessary to address: independent musician, child centered / learner centered, or constructivism writ large, learning outcomes, and finally the space in the elementary setting for the kinds of pedagogical engagements and purpose Allsup outlines throughout his text.

Keywords: independent musician, constructivism, learning outcomes, guilty readings

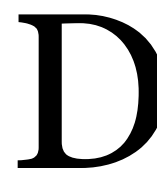

uring the fall of 2016 I was invited home to Teachers College, Columbia University to be a member of a panel that was convened to respond to Randall Allsup's (2016) book, Remixing the Classroom: Toward an Open Philosophy of Music Education. Of course, Teachers College (TC) is not my familial home, but rather the home of my awakening as a scholar and intellect. I submit this is the same for Allsup. We had both arrived at TC after teaching in schools, both seeking new ways of thinking: Randall in the Faculty of Music, me in Curriculum and Teaching. While our paths did not cross during our studies it was Wayne Bowman who suggested, that as two like-minded souls in NYC, we should get together. We sat for coffee, rather uncomfortably (almost like a forced blind date), during a New York State School Music Association (NYSSMA) conference. It didn't take long for us to discover that our shared backgrounds, shaped by the joys and abuses of growing up "musician," meant for the most part that neither of

(C) Cathy Benedict. 2017. The content of this article is the sole responsibility of the author. The ACT Journal and the Mayday Group are not liable for any legal actions that may arise involving the article's content, including, but not limited to, copyright infringement. 
us had been prepared for the requisite critical engagement of TC. Interrogation of norms and assumed practices lay at the heart of our doctoral studies and multiple spaces of inquiry were opened at TC that had not been previously available to us. Randall found philosophical grounding as he worked with Maxine Greene and I with the critical theorists. There was a university wide expectation all of us would leave TC as leaders and thinkers in our chosen disciplines; each of us groomed to "shape the public debate and public policy in education." And Randall has certainly fulfilled this expectation in ways more than one.

The confluence of TC's mission with the joys and abuses of "musician," constructed a voice in music education that has now, and for many years, made interrogation a moral imperative. For better, never for worse, the wind band world will never be the same. And for this Randall has been accused of "bandying about" democracy, referred to as an academic elitist, and my personal favorite, "needlessly divisive." 2 While these may be "aspersions" for some, few can deny his voice has helped to shape public debate in our discipline. And certainly, for most readers of ACT, this kind of name calling, rather than disparaging, implies strength of character, rectitude, a willingness to enter and disrupt, to think anew, over and over.

It was both fascinating and intimidating to be invited to join the TC book panel. Rather than musicians or music educators the other two panelists were (and are) both grounded in socially just practices in their respective fields. Dr. Lalitha Vasudevan, whose work explores the intersection of adolescent literacies, media and technologies, youth culture, and juvenile justice, entered Randall's text reading for far reaching possibilities and potential. She did this in such a way that a room filled with musicians transcended the confines of music education and wandered with her as she made connections to issues of fluidity and belonging. The other panelist, philosopher David Hansen, spoke of the moral and ethical grounding of Randall's text, particularly the ways in which Randall's processes of inquiry consistently reflected a valuing of care with both narrative and subject. Hansen (2005) writes of the potential (and significance) teachers wield in their "moral influence" on students and reminds us that this is not just style or personality, but rather moments that "occur in an indirect and unpredictable way that is not easily identified" (398). Randall could not have predicted the ways in which his text might influence the thinking of other's. He can only be cognizant (indeed, all of us

Benedict, Cathy. 2017. Spaces of rupture: Wondering, wandering, remixing. Action, Criticism, and Theory for Music Education 16 (1): 79-94. doi:10.22176/act16.1.79 
can only be cognizant) of our "deeply held assumptions" (420) about what it is we can do.

I mention the other panel members because there are many ways and places one can enter Randall's text-which Randall reminds us is all we can do; enter with openness, with a willingness to ponder and consider. Randall's text offers multiple openings that invite us to "be dragged in the wake of this first reading into a second one which will take us still further" (Allthusser 1968, 14). I embrace this sentiment, as I contemplate what it means to read, to enter texts, to be "guilty of reading" (Allthusser 1968). To be guilty, in Allthusser's thinking, means to take responsibility for one's reading and "to activate the text within the history of thought, and against certain strands within that history" (Wolfreys 2004, 256). I activate Randall's text against other philosophy texts that have been written in our discipline and realize how easy it is to read these texts for use-value. Of course, reading for use is what we have been taught to do. We read for various reasons; to comprehend, to obtain knowledge, for recreation, to recall, to replicate, and even to "broaden worldviews" (National Governors Association Center for Best Practices 2010, 3). Rarely, however, are we asked to consider our relationship to the text, and with the process of reading.

In a discipline where there have been a handful of influential philosophical texts (in the presentation of books), sovereignty can appear in the guise of assurance and sanctuary. As if the finality of purpose has definitively been answered, this illusion of sovereignty fills a void signaled perhaps by a sense of disciplinary loss, or the "reactive nihilism," of which Bowman (2005) writes. The problematics, then, of reading for use-value lay in the desire to mine a text, as it were, in order to lay waste to that which deviates or contradicts sovereign tenets.

What I read in Randall's text is not the embracing of 'anything goes', but rather a yearning for what Kanellopoulos (2007) refers to as "open contexts for acting and thinking" (98). I believe this book to be first and foremost a physical manifestation of Randall's grappling with what it means to be in the world; both as a human, and in and through sonic relations. It makes sense that Randall takes issue with the Master/apprentice binary, or antinomy. Randall lives a pedagogy of dissolving, in his words "dissolv[ing] in a way that is unfinished and ongoing," in which Randall "is a bit of both but neither, too-rather, something new" (41). Randall's rather "something new" is woven throughout each page calling us to contemplate form

Benedict, Cathy. 2017. Spaces of rupture: Wondering, wandering, remixing. Action, Criticism, and Theory for Music Education 16 (1): 79-94. doi:10.22176/act16.1.79 
and its totalitarian (my use of the word) grip on all things; most cripplingly, the inability to believe in a universe of disparate sources and the all too common inability to trust in one's musical capabilities. His own thinking, grounded securely in that of John Dewey and Maxine Greene (and I would add by extension Hannah Arendt, and the free improvisation voice of philosopher Panos Kanellopoulos), speaks to the creation of freedom, and the "revelation of self with others-teaching for openings" (103). To that end, I find spaces in my own engagement with this text in order to "expand on certain themes, fill in possible gaps." 3 While I ardently believe there are more "right" ways than others to enact (embrace, live, breathe, be) pedagogy, I am not interested in furthering my identity based on either/or positioning. So, what I can, and do offer in this text are the following considerations for further "thinking through." These are considerations, given Randall's framing, that I feel are necessary to address: independent musician, child centered / learner centered, or constructivism writ large, learning outcomes, and finally the space for this pedagogy in the elementary setting.

\section{Independent Musician}

Firstly, the construct of independent musician: too often held as the apex to which all should strive in our discipline, and yet one I suggest must be interrogated as it is raised in this text of openness. Recall the meeting in the Times Square café in which the concept of independence as a musical standard is considered. The National Association for Music Education (NAfME) had approached Randall and Eric Shieh to write a position paper that would be used to "craft new Common Core Standards in music education" (111) and Eric and Randall were to define benchmarks that could "foster independent musicianship among learners" (112). Had I been there with Randall and Eric I would have suggested, as they sketched out a relationship between independence and freedom, that neither Greene nor Arendt would have agreed with the concept of independence as freedom. And while Randall (and Eric) do make clear this discussion of independence takes place because they were approached by NAfME, I would have urged them to consider that independence, wielded by NAfME and others, is a goal that serves to enfold competition and the free market that serves to "produce economically productive workers for the new knowledge economy" (111). Independence, thus rendered, is simply another tool, a capitalistic productive strategy of the neo-liberal agenda. Recognizing

Benedict, Cathy. 2017. Spaces of rupture: Wondering, wandering, remixing. Action, Criticism, and Theory for Music Education 16 (1): 79-94. doi:10.22176/act16.1.79 
that no one reading this needs to be schooled in post-capitalism, this is an agenda that favors hyper-individuality and pedagogy that serves to "exclude, to divide, and to marginalize" (Rand 2012, 77). Perhaps a discussion with NAfME would have helped to have emphasized how Greene (1984) might interpret their request through a lens of negative freedom in which the presence of others is not just undesirable, but rather vital to the continuance of the pursuit of hyper-individual excellence. For Arendt (1953), this formation of independence (as negative freedom) eschews the plurality of others and as such, represents a foundational element of what makes totalitarianism possible. Benchmarking independence as a measurable standard furthers "approaches that view knowledge and skill acquisition as linear and progressive processes" (Kanellopoulos 2007, 98), and thus, a form of musicking that renounces the primacy of the public space. I do not think it is a stretch of the imagination to recognize the fervent musician spending hours alone, taking refuge in a practice room, submerging herself in the work of dismantling self in order to reemerge independent, losing, nay denying, the capacity for thought and experience in the public space. This kind, of independence, as it were, as isolation, where "self and the world, capacity for thought and experience are lost at the same time" (325) is qualitatively different than independence constructed as solitude, as a necessary place to gather thought, to think, to examine, to contemplate.

All of this to say, that while Randall (and presumably Eric) do wend their way toward considering what independence might look like in an open classroom, it is not clear what, if anything, was presented to NAfME, and where the matter ended. I suspect my concern is the cooptation of both Randall and Eric, even the allowance of their names as consultants, in a document that surely is not going to go with "independence seen as antithetical to the values of freedom" even if "evaluat[ed] ... through dialogue and debate" (111). The moral high ground (indeed) would suggest taking a non-start position: the word independence, no less than a "state mandated" (111,) benchmarked standard, needed at the very first, to be dissolved, violated and discarded. Which leads to my second point of consideration...

\section{Constructivism}

While this article is not the place to completely dismantle ambiguous, unclear, confusing, and philosophically vague constructivist principles, we might agree that

Benedict, Cathy. 2017. Spaces of rupture: Wondering, wandering, remixing. Action, Criticism, and Theory for Music Education 16 (1): 79-94. doi:10.22176/act16.1.79 
this term has, in many ways, become too inviolable to interrogate. I do offer however the following to substantiate the points I have already made.

Constructivism is, first and foremost an epistemological concern, a theory of learning. Recognizing that multiple epistemological paradigms exist, including social and psychological (Richardson 2003), conditions (Kitcher 2011) and contexts; cultural (Gottlieb 2007), communicative, (Origgi 2008), metaphysical and semantical (Williams 2015), discipline specific and place-based (Gruenewald 2003), one might certainly conclude that there needs be more care taken when claiming constructivism.

The use of the word constructivism is rarely situated in the vast constructivist literature and used more often than not as an implied alternative to a less-desirable "teacher-centered" practice (Heidel 2002; Criswell 2008; DeGroot 2008), 4 our antinomy, as it were. On the other hand, 'child centered', even 'learner centered', is not just embedded in the rhetoric of creativity, participation, social skills, and social justice (terms linked to communal and public actions). It is also unabashedly found within models that are linked to efficiency and global market place accountability, rhetoric that is unmistakably used to argue economic benefits. The childcentered/teacher-centered positioning creates a false binary and covers questions that really ought to be asked. Randall writes that constructivism is "underutilized as a teaching strategy" (73). Indeed, this certainly is the case in that there are few, if any in our discipline, who have taken the time to tease out the ways in which particular forms of constructivism falsely reject that knowledge can be shared and communicated between and among both teacher and student. Surely, then, Randall's interrogation of the master/apprentice should be extended throughout all curricular models in order to challenge similar pedagogical approaches that favour certain epistemological perspectives over others.

I'm not sure I agree with Randall, nor do I believe Arendt or perhaps even Greene (and most certainly not Freire) would, when Randall writes, "Necessarily, the questions begin with the learner, but they quickly direct us to the unique role the teacher plays" (36). Well, yes and no. Yes, in that the teacher must play a role in the space that may open. But no, in that the space cannot open unless all feel equal to speak. Who speaks first then uncovers the question of naming. Student? Learner? Teacher? The affordance of the production of voice (where voice signifies musicing, working, questioning, etc.) is not the same as allowance. Allowing for

Benedict, Cathy. 2017. Spaces of rupture: Wondering, wandering, remixing. Action, Criticism, and Theory for Music Education 16 (1): 79-94. doi:10.22176/act16.1.79 
voice would suggest a master of production (Biesta, 2015). All which leads to two further considerations.

Firstly, it's not that the "Master must learn how to share" (68) it is more rather (in the parlance of progressive children playground negotiations in NYC) that the Master must learn how to take turns. Sharing indicates the taking of something and not giving it back-you share food. Taking turns in the playground, means negotiating engagements, and hopefully, once you move beyond the age of three, it also means engaging in performative listening, or listening toward relationships (Srader 2015, 95).

The question then is not, "do we teach a tradition or do we teach a child" (65). It would seem we don't "teach" at all, as the use of the word indicates there is an order to speaking "where," as Biesta (2015) writes, some claim the power to let others speak and where some see themselves as in need of recognition by powerful others before they feel they can speak... (545). There is a fine line then, between an authoritarian relationship and one in which there is recognition that something new has been brought into the world that had not been previously known (Arendt 1953; Biesta 2013). The space then, to teach, or to have been taught, is not defined by a gift given by "the teacher at the center of the event" (Sæverot 2011, 564), where what is taught is transmitted through hundreds of years of tradition. Thus, teaching is not validating something already possessed, but rather a gift that "truly transcends what they already know" (Biesta 2013, 50). The teacher is not simply a resource, nor are we pulling something known from within, since we can't know what is known. And as we can't predict when the gift of teaching is received teaching must become a "circle of exchange" where we "desire to give something without getting anything back" (Higgins 2008, 333). Thus, we must afford the rupture, the space, reserve, solitude and wait for the first speaker, indeed, the "shock of something new" for a world not used to silences. We need to trust that questions will emerge as we wait and listen with each other. Which brings me to my nearly final consideration...

\section{Learning Outcomes}

Objectives without assessments are rarely more than rhetoric. (Popham 2001, 10)

I agree with Randall (90) that learning outcomes are mired in closed systems of behaviourist accountability. Statements that are framed by the performative

Benedict, Cathy. 2017. Spaces of rupture: Wondering, wandering, remixing. Action, Criticism, and Theory for Music Education 16 (1): 79-94. doi:10.22176/act16.1.79 
"students will" forward a definition of 'learning' that many find problematic. Not only do they predict (and thus, determine) what will be 'learned' (leaving no space for generative movement), they also dictate how that learning will be transmitted, or the "instructional sequence" (Popham 1971, 77). Randall asks, "what would it mean to search out ... points of novelty and surprise at each level of relation and intersection, at every level of signification, from individual to individual, from object to text, from moment to moment" (127)? It would necessitate first and foremost a critical interrogation of the assumed benefits of measureable objectives. It would mean to irrefutably conclude that learning objectives avert surprise. And finally, viewed as codes of power, that this obstruction of novelty and surprise is purposeful.

Because I work with pre-service teachers and know they will be held accountable for crafting these kinds of statements in their own teaching situations I take the problematics of learning outcomes quite seriously; indeed, as a "moral encounter" (Allsup, 127). To that end, I offer the following learning outcomes that move toward this surprise and openness of possibilities for self, others and community. Rather than endpoints I reframe these Western Learning Outcomes in such a way that privileges processes as well as articulate the reflexive responsibility for both teacher and student.

- Students/teachers will continually move toward a sense of discovery that drives their ability to ask and frame questions, always seeking to make connections that are not immediately obvious among phenomena and ideas.

- Students/teachers will continually move toward exploring complex problems from a variety of perspectives, recognizing bias, and identifying missing voices.

- Students/teachers will continually move toward interacting ethically and compassionately with others and with the natural and social world.

- Students/teachers will continually move toward interacting and collaborating mindfully with other individuals and groups using the language and reasoning appropriate to the communicative context, within and across their personal and professional communities and cultures. (Western Degree Outcomes) ${ }^{5}$

I recognize that simply changing the wording of behavioral objectives does little to challenge larger dominant paradigms of what it means to know. Behavioral objectives are, in the words of Delpit (1988), "codes or rules for participating in power" (282) and as such, discussions need to accompany these reframed outcomes. Who does and who doesn't benefit from the "culture of power" (282), and how these outcomes came to be, helps to focus on the ways (and the whys) in which outcomes, stated in behavioral terms, specifically and explicitly shut down "points of novelty

Benedict, Cathy. 2017. Spaces of rupture: Wondering, wandering, remixing. Action, Criticism, and Theory for Music Education 16 (1): 79-94. doi:10.22176/act16.1.79 
and surprise." As such, discussions with students and colleagues (much more difficult, but essential) can "ignite agency" and "become acts of freedom" (Allsup, 91). Moreover, if indeed the above quote of Popham's holds true, then assessing continual movement forward relies on formative frameworks of assessment. Formative assessment or "assessment for learning" (Bennett 2011, 5), however, is contingent upon epistemological assumptions based on a 'thing already known' and therefore "resists explanations about the complications we live" (Britzman 1991, 7). Additionally, if the goal is for the student to "become independent and fully self-monitoring" (Sadler 1989, 120) formative assessment is simply another "colonizing tool" (Schmidt 2017) constructing, once again, the authority of closed space under interrogation. Clearly, this is not the space for the philosophical interrogation of assessment, but just as clear are the ways in which even the "creation and revision" of individual rubrics will still be, at the very least, a "hindrance," even in the "qualitative setting" (Allsup, 113) of an open classroom.

\section{The Primary and Elementary Space}

What would it mean to search out, within one's classroom community, "points of novelty and surprise at each level of relation and intersection, at every level of signification, from individual to individual, from object to text, from moment to moment" (Allsup, 127)? My last point of entry into Randall's text brings me to that of elementary spaces. He reminds us that "How we teach music sets into motion one way of being in the world and not another" (25). This applies just as much, if not more so, to our encounters in the elementary setting. I have spent my teaching career with either young ones or pre-service college students who will interact with young ones. Having never taught elementary it makes sense this community would not be Randall's focus. But it has been mine. Thus, I can attest to the following. First, one assumes that openness, novelty and surprise is a given in this setting. Two, it is not. In fact, banning the teaching of ABA form (Allsup, 21) is the very least of our worries and simply a manifestation of a much more systemic issue. From the earliest beginnings of pre-readiness literacy, how to develop a sequenced order for and of thinking, and the linear development of an idea, is drilled into preK children. Fill in the blank "learning" activities come first: I like... I see... I can... I am... Sentence starters are next: 1) Recount two or more appropriately sequenced events, 2) include some details regarding what happened, 3) provide more details

Benedict, Cathy. 2017. Spaces of rupture: Wondering, wandering, remixing. Action, Criticism, and Theory for Music Education 16 (1): 79-94. doi:10.22176/act16.1.79 
regarding what happened, 4) use temporal words to signal order, and 5) provide some sense of closure. (Common Core State Standards) ${ }^{6}$. All of which lead to the acme of "closed-form culture" (Allsup, 55), the Holy Grail of what must be the most controlling construction of epistemology: The Five Paragraph Essay, with its obvious introduction, three paragraph body, and conclusion.

Unfortunately, the construction of a five-paragraph essay is too often represented in the way students are taught to "listen" to music, and engage with improvisation and composition projects. Too many teachers continue to believe that without a "foundation" students won't be able to... (fill in the blank), unless they, as teachers ... (fill in the blank). Teaching that is grounded upon 'best intentions', where students, based on their lack, are 'assisted' in their learning (and thus, creation of self) prevents contexts that could facilitate "moments beyond meaning" (Allsup, 89). What better place to recognize the possibility of "the shock of something new, the rupture of an open encounter" (90) than the elementary space? No matter what the context the interconnectivity of pedagogy and curriculum can either open or shut down a "location of freedom" (31).

Children, for instance, take great delight in words that have double meanings. There are many of these songs and many have accompanying movements that serve to reveal the double nature of words. "Tony Chestnut Knows I Love You," is one of these songs. 7 There are several ways to teach this song. You can simply sing the song and perhaps have a cursory conversation about who is in the song and what Tony Chestnut knows. Or you can begin with the second meaning of the words pointing to the body parts while you sing, "Toe Knee Chest Nut Nose Eye Love You." 'Teaching' the names of body parts is certainly a 'time-honoured goal' with young children. And simply singing the song is quite lovely and opens spaces for conversations as to Tony Chestnut's gender (Is Tony a boy, a girl, a...? How do we know?), and the knowing of love. But one without the other denies the space of joy. Beginning with Toe Knee Chest Nut Nose Eye Love You (and pointing to body parts)-shuts down the moment of discovery (indeed, surprise and novelty) that happens when children find "insight beyond fact, experience beyond description, a euphoria that is only understood in the present..." (Allsup, 89). This may seem an insignificant example, but the preemptive closure of this text, suggesting there is "a need for fixing-or silencing" (Allsup, 79), denies a space that appears when each of us, in the company of others, realizes the ways in which the mercurial shifts

Benedict, Cathy. 2017. Spaces of rupture: Wondering, wandering, remixing. Action, Criticism, and Theory for Music Education 16 (1): 79-94. doi:10.22176/act16.1.79 
in language offer wondrous openings. Text after text after text will close as we continue to break down exquisite, aesthetic wholes into parts, before experiencing alternatives and possibilities, reinscribing the rightness of doing such violence. Tony Chestnut is simply just the beginning of a path toward becoming the reader who does not read, "but who awaits the arrival of the reading from some other place, as though everything that could be said, had been said, as though reading were over, and the text had said it all” (Wolfreys 2000, 10).

\section{Lingering Thoughts}

Forgiving is the only strictly human action that releases us and others from the chain and pattern of consequences that all action engenders; as such, forgiving is an action that guarantees the continuity of the capacity for action, for beginning anew, in every single human being who, without forgiving and being forgiven, would resemble the man in the fairy tale who is granted one wish and then forever punished with that wish's fulfillment. (Arendt 2005, 59)

Buried in his text Randall writes, "our job is to secure the conditions-nothing more-such that a new generation can make something of happiness in their moment in time" (81). This is the responsibility to which Greene, and thus, Arendt address. We can't change what has come before neither can we predict the ramifications of our actions. I read in Randall's work the desire to continue to grapple with, meet and figure out, places of promise and forgiveness as Greene and Arendt would want us to. This isn't just the forgiveness that comes with growing olderbut rather responsibility as action and the promise of commitment. Edgoose (2010) reminds us that both are "vital for [the] student to be open to the unexpected" (401). It is by this commitment, then, we demonstrate our desire to be with and in each moment, and the recognition of unpredictability and thus, "an acknowledgement and validation of the student's experience (401).

Woven throughout each page of Randall's text I am reminded of the ways in which closed forms may serve as an opiate, the blue pill, as it were. This is a text that reminds us what a necessary place "uncertainty ... play ... access ... democracy [and] innovation" (55) has in our educative and public spaces. These are the conditions that secure plurality and the public space of dialogue. Happiness thus construed.

John Finney, noted music educator and scholar at the University of Cambridge, when commenting on Randall's book, wrote these words in a blog, "Oh,

Benedict, Cathy. 2017. Spaces of rupture: Wondering, wandering, remixing. Action, Criticism, and Theory for Music Education 16 (1): 79-94. doi:10.22176/act16.1.79 
how I would have loved to have written this book." Indeed. Oh how. Finney speaks to Randall's "vision and sense of purpose with a rootedness in classroom encounters." 8 These are encounters that embrace continual movement and change; ones that consistently consider our relationship to the text. Maxine Greene, Randall's colleague and friend, had she been able to read this book, quite possibly might have said, "[Randall] has not taught us new truths, but he may have made us see what we already knew somehow differently" $(1984,294)$. Oh how.

\section{About the Author}

Dr. Cathy Benedict is Director of Research for the Don Wright Faculty of Music, University of Western Ontario. As a music education professor she has presented multiple workshops to national/international audiences on topics such as elementary pedagogy, discourse analysis, philosophical interrogations of pedagogy and curriculum, ethics of functional literacy, and the representation of reality. She has written numerous chapters and published in journals such as Canadian Music Educator, Philosophy of Music Education Review, Music Education Research, and Research Studies in Music Education, co-edited the journal Theory Into Practice, and most recently co-edited The Oxford Handbook of Social Justice and Music Education (Oxford University Press).

\section{References}

Allsup, Randall E. 2016. Remixing the classroom: Toward an open philosophy of music education. Indiana University Press.

Allsup, Randall E., and Cathy Benedict. 2008. The problems of band: An inquiry into the future of instrumental music education. Philosophy of Music Education Review 16 (2): 156-73.

Althusser, Louis, and Étienne Balibar. 1968. Reading Capital. Paris: François Maspero.

Arendt, Hannah. 1953. Ideology and terror: A novel form of government. The Review of Politics 15 (3): 303-27.

Arendt, Hannah. 2005. The promise of politics. New York, NY: Schocken Books.

Bennett, Randy Elliot. 2011. Formative assessment: A critical review. Assessment in Education: Principles, Policy \& Practice 18 (1): 5-25.

Benedict, Cathy. 2017. Spaces of rupture: Wondering, wandering, remixing. Action, Criticism, and Theory for Music Education 16 (1): 79-94. doi:10.22176/act16.1.79 
Biesta, Gert J.J. 2013. Beautiful risk of education. Boulder, CO: Paradigm Publishers.

Biesta, Gert J.J. 2015. Learner, student, speaker: Why it matters how we call those we teach. Educational Philosophy and Theory 42 (5-6).

Bowman, Wayne. 2005. Music education in nihilistic times. Educational Philosophy and Theory 37 (1): 29-46.

Britzman, Deborah. 1991. Practice makes practice: A critical study of learning to teach. Albany: State University of New York Press.

Criswell, Chad. 2008. Music technology: The value of podcasting. Teaching Music 16 (2): $26-7$.

DeGroot, J. 2008. Voice health problems: Symptoms and suggestions. Teaching Music 16 (3): 54-5.

Delpit, Lisa D. 1988. The silenced dialogue: Power and pedagogy in educating other people's children. Harvard Educational Review 58 (3): 280-99.

Edgoose, Julian. 2010. Hope in the unexpected: How can teachers still make a difference in the world? Teachers College Record Volume 112 (2): 386-406.

Fonder, M. (2014). Another perspective: No default or reset necessary-Large ensembles enrich many. Music Educators Journal 101 (2): 89.

Gottlieb, Eli, and Mandel Leadership Institute. 2007. Learning how to believe: Epistemic development in cultural context. The Journal of the Learning Sciences 16 (1): 5-35.

Greene, Maxine. 1984. Excellence, meanings, and multiplicity. Teachers College Record 86 (2): 283-97.

Gruenewald, David A. 2003. Foundations of place: A multidisciplinary framework for place conscious education. American Educational Research Journal 40 (3): 632.

Hansen, David T. 1993. The moral importance of the teacher's style. Journal of Curriculum Studies 25 (5): 397-421.

Hansen, David T. 1994. Teaching and the sense of vocation. Educational Theory 44 (3): 259-75.

Benedict, Cathy. 2017. Spaces of rupture: Wondering, wandering, remixing. Action, Criticism, and Theory for Music Education 16 (1): 79-94. doi:10.22176/act16.1.79 
Heidel, Richard Mark. 2002. Get a head start on your professional development. Teaching Music 9 (5): 34-9.

Higgins, Lee. 2008. The creative music workshop: Event, facilitation, gift. International Journal of Music Education 26 (4): 326-38.

Kanellopoulos, Panagiotis A. 2007. Musical improvisation as action: An Aendtian perspective. Action, Criticism, and Theory for Music Education 6 (3): 97127.

Kitcher, Philip. 2011. Epistemology without history is blind. Erkenntnis 75 (3): 505-24.

National Governors Association Center for Best Practices, Council of Chief State School Officers. 2010. Common core state standards. Washington, D.C.: National Governors Association Center for Best Practices, Council of Chief State School Officers.

Origgi, Gloria. 2008. Trust, authority and epistemic responsibility. Theoria 23 (61): $35-44$.

Popham, W. James. 1971. Practical ways of improving curriculum via measurable objectives. NASSP Bulletin 55 (355): 76-90.

Popham, W. James. 2001. Whittling wish-list standards down to reality. The Education Digest 66 (7): 8.

Rand, Erin J. 2012. Gay pride and its queer discontents: ACT UP and the political deployment of affect. Quarterly Journal of Speech 98 (1): 75-80.

Richardson, Virginia. 2003. Constructivist pedagogy. Teachers College Record 105 (9), 1623-40.

Regelski, Thomas A. 2014. Resisting elephants lurking in the music education classroom. Music Educators Journal 100 (4): 77-86.

Sadler, D. Royce. 1989. Formative assessment and the design of instructional systems. Instruction Science 18: 119-44.

Sæverot, Herner. 2011. Kierkegaard, seduction, and existential education. Studies in Philosophy and Education 30 (6): 557-72.

Schmidt, Patrick. 2017. Assessment and the colonialization of the teaching subject: Educational policy in the absence of educators. The 11th International Symposium on the Philosophy of Music Education.

Benedict, Cathy. 2017. Spaces of rupture: Wondering, wandering, remixing. Action, Criticism, and Theory for Music Education 16 (1): 79-94. doi:10.22176/act16.1.79 
Srader, Doyle W. 2015. Performative listening. International Journal of Listening 29 (2): 95-102.

Williams, David A. 2011. The elephant in the room. Music Educators Journal 98 (1): $51-7$.

Williams, Michael. 2015. What's so special about human knowledge? Episteme 12 (2): $249-68$.

Wolfreys, Julian. 2000. Readings: Acts of close reading in literary theory. Edinburgh University Press.

Wolfreys, Julian. 2004. Occasional deconstructions. State University of New York Press.

\section{Notes}

${ }^{1}$ Teachers College Mission Statement. http://www.tc.columbia.edu/abouttc/

${ }^{2}$ Mark Fonder (2014) Another perspective: No default or reset necessary-Large ensembles enrich many. Music Educators Journal 101 (2): 89. Of course, Randall wasn't the only one indicted in this column. Others have written about large ensembles. See Randall E. Allsup and Cathy Benedict (2008) The problems of band: An inquiry into the future of instrumental music education. Philosophy of Music Education Review 16 (2): 156-73. Thomas A. Regelski (2014) Resisting elephants lurking in the music education classroom. Music Educators Journal 100 (4): 7786. David A. Williams (2011) The elephant in the room. Music Educators Journal 98 (1): 51-7.

3 Guidelines: ACT Projects involving Essay Reviews and/or Author Responses.

4 This citation was brought to my attention by Shannon Hibbard in our joint presentation at the 2016 NAME Philosophy SRIG: The Lost Pedagogical Core of "Student Centered" Teaching.

5 These outcomes can be found on the following website:

https://www.uwo.ca/tsc/resources/publications/newsletter/current_issue/introduction_wdos.html

${ }^{6}$ National Governors Association Center for Best Practices, Council of Chief State School Officers (2010). Common Core State Standards. English Language. National Governors Association Center for Best Practices, Council of Chief State School Officers, Washington D.C.

Benedict, Cathy. 2017. Spaces of rupture: Wondering, wandering, remixing. Action, Criticism, and Theory for Music Education 16 (1): 79-94. doi:10.22176/act16.1.79 
7 As part of my presentation at the TC book panel I taught this song to the audience as I would with children. For those interested the following link will take you to a video of me teaching this song:

https://www.youtube.com/watch?v=gZtFvqDKFFo\&list=PLlK_hoQRDv2LHTO QlD5r47vL_2WUuNtol

8 https://teachtalkmusic.wordpress.com/2016/o9/o3/what-is-ks3-music-education-for/

Benedict, Cathy. 2017. Spaces of rupture: Wondering, wandering, remixing. Action, Criticism, and Theory for Music Education 16 (1): 79-94. doi:10.22176/act16.1.79 